\title{
Career Development, TNI AD Officers in the Environment Military Regional Command V/Brawijaya of Indonesia
}

(Implementation Study Based on KEP. KASAD No. 483 of 2014 concerning Career Development for Army Officers)

\author{
Slamet Winarto, Kasuwi Saiban, Tommy Hariyanto
}

University of Merdeka Malang, Indonesia

\begin{abstract}
Career development for TNI AD officers as we all know is different from career development carried out by other agencies and organizations. The career development of officers in the Kodam V/Brawijaya organization must be carried out in a planned and continuous manner so that optimal results will be obtained in increasing the professionalism of Kodam V/Brawijaya soldiers which are demands that must be answered to face the challenges of future tasks that are increasingly complex according to the increasingly advanced times and modern. The purpose of this study is to describe and analyze the implementation of the career development for TNI-AD officers at Kodam V/Brawijaya in 2019 based on KEP. KASAD No. 483 of 2014 concerning Career Development for TNI AD Officers and describing and analyzing the factors that support and hinder the implementation of Career Development for TNI-AD Officers at Kodam V/Brawijaya in 2019 based on KEP. KASAD No. 483 of 2014 concerning Career Development for TNI AD Officers. To reveal this reality, a qualitative research method is used where the data obtained is processed by organizing and sorting data into patterns or categories and basic unit descriptions so that they can be read and interpreted. Based on the facts and phenomena obtained in the field, the following research results are obtained: First, career development for officers in the form of dismissal and appointment of positions and transfer of positions of officers is carried out by taking into account the periodization, family of positions and parameters of officers' positions in accordance with the norms and process of lawyers. Second, the implementation of the promotion of officers as a form of career coaching consists of promotion of awards and regular promotions, the implementation of which starts with proposals, the implementation of promotion sessions according to the structure then the results are compiled for updating. Third, the selection of education for officers as part of career development is divided into various categories and stages with the aim of increasing the ability of officers to anticipate changes in the national environment. The factors that influence the career development of TNI AD officers consist of Internal Factors in training soldiers in the form of welfare, morale, mental, discipline and skills of soldiers and Internal Factors in training soldiers in the form of welfare, morale, mental, discipline and skills of soldiers in personnel development. at Kodam V/Brawijaya. Career development for officers must be supported by welfare in order to support high morale and mentality as well as discipline and skills for officers to carry out their duties and challenges ahead. The Policy Mechanism for the career development of this officer begins with dismissal and appointment in a position and transfer of position, rank and selection of education will not run optimally if it is not supported by adequate funding sources. The major proposition in this research is the implementation of career development for TNI AD officers with a focus on the policies of dismissal, appointment in position, transfer of positions, ranks and selection of education aimed at the successful implementation of TNI AD tasks.
\end{abstract}

Keywords: Career Development, Officer, Position, Rank, Educational Selection.

\section{INTRODUCTION}

Career development as part of personnel development includes activities to achieve the fulfillment of proper norms of position, rank and education. In its implementation, the three elements of career development must be in line and interrelated with one another in order to obtain optimal results. The limited office space for officers in the TNI AD today has an impact on the smaller number of officers who can reach higher positions. Therefore an accurate and objective selection is needed, so as to provide opportunities for all TNI AD Officers to have the same opportunity to pursue a career in the TNI AD. These opportunities include aspects of assignment, promotion, promotion and opportunities to take education in levels according to the career path. 
However, the current condition of career development for TNI AD officers is felt to be stagnant, this is because the number of eligible officers is faced with an imbalance of available office space. Therefore an accurate and objective selection is needed so that every officer has the same and fairest opportunity according to his dedication to develop his career to reach the Top Manager Level in the TNI AD. To achieve this, it is necessary to apply a very selective and measurable pattern of career development for officers, supported by clear parameters and accountability for the level of objectivity. Currently, the office space for officers is increasingly limited with a personnel pyramid or in terms of the smaller office space. Judging from the office space, the consequence is that fewer officers will reach higher positions. Therefore, an accurate and objective selection is needed, so that officers have the same and fairest opportunities in their service to develop careers in the TNI AD. Starting from these objective conditions, the career development policy for TNI AD officers provides opportunities for all officers to have equal opportunities in pursuing careers in the TNI AD, covering several aspects. These aspects include aspects of assignments, promotions, promotion and the opportunity to pursue a tiered education according to the career path he is taking. However, it is felt that career development has not paid attention to objective aspects of service.

Limited office space is closely related to the career selection of officers for future TNI AD leadership candidates. Because with the existence of an appropriate and objective career selection for officers, a well-planned, directed and continuous career coaching of officers will provide the widest possible opportunity for officers to develop their careers and will overcome the increasingly limited office space where the officer's office space is getting smaller according to the Pyramid. personnel. The career selection for TNI AD Officers is carried out by taking into account aspects of achievement in education, assignments at home and abroad and other achievements such as achievements in unit development, written works and scientific works. In order to get qualified and professional cadres of future TNI AD leaders as thinkers, initiators, activists, determinant and person in charge of task success, in this study several aspects used in officer career selection are aspects of promotion, education, assignment and promotion as well as performance appraisal and direct evaluation (Fit and Propert Test) by TNI AD officials or direct observation. in the field as well as indirect assessments. This can be done through periodic or incidental reports from Kotama or Balakpus regarding the performance concerned in the context of fostering career officers as cadres of the TNI AD leadership. However, all of this must be adjusted to the officers 'career development policies as the basis for officers' career selection in order to form a cadre of TNI AD leadership.

In general, the career development strategy starts at the time of recruitment, education, placement, and career development of officers so that competency development of officers is not an instant activity. A competency-based career development system for officers needs to emphasize efforts to identify potential officers such as initiative, achievement motivation and ability to work within the organization. Efforts are being made to use as many sources of information as possible about officers so that it can be determined whether these officers have the competencies required in the TNI AD organization. The method of appraising officers can be done through talent scouting, competency, sociometry and assessment lists.However, this collided with the policy of extending the Service Period for Officers. In Law Number 34 of 2004 concerning the TNI, Article 53 states that officers carry out the official service until a maximum age of 58 (fifty eight) years. We all know that recently in the TNI AD there have been various problems. Among other things, these problems are related to career development, namely the obstruction of promotion to positions, especially middle officers.

This is due to the policy of extending the retirement age for officers from 55 years to 58 years and the lack of Indonesian Army officers interested in ending active service (early retirement). The generally accepted extension, without certain strict conditions resulted in a buildup of personnel at the rank of Colonel. From this it is clear that the policy of extending the retirement age has not considered future impacts. Then what is the solution so that there are no problems with career development at the middle officer level? There are several possible solutions to solve this problem. Such as the addition of a new organization, a much tighter career selection and provision of early retirement and distribution through a second carrier. The addition of a new organization can reduce the level of stagnation, but it comes at a costly price. Like it or not, an additional defense budget will be absorbed to finance the new organization. Military organizations are still treated as labor intensive. The policy for extending the retirement age is a reflection of this approach. It is time for a comprehensive and correct study on the issue of how much personnel actually need TNI AD officers. The second option can be applied, provided that starting from the lowest rank of the officer. By comparison, in other countries not all officers starting out with the rank of Second Lieutenant or equivalent. The policy for extending the retirement age is a reflection of this approach. It is time for a comprehensive and correct study on the is sue of how much personnel actually need TNI AD officers. The second option can be applied, provided that starting from the lowest rank of the officer. By comparison, in other countries not all officers starting out with the rank of Second Lieutenant or equivalent. The policy for extending the retirement age is a reflection of this approach. It is time for a comprehensive and correct study on the issue of how much personnel actually need TNI AD officers. The second option can be applied, provided that starting from the lowest rank of the officer. By comparison, in other countries not all officers starting out with the rank of Second Lieutenant or equivalent. 
Overall, there are three factors that cause the career stagnation of officers in the Indonesian Army. First, the change in retirement age as stipulated in Article 71 of Law Number 34 Year 2004. This article mandates an extension of the retirement age for officers from 55 years to 58 years, resulting in an extension of the service period for officers for 3 years. Several years after the enactment of this law, there is an imbalance in the composition of the TNI Officers that has continued until now. On the one hand the TNI has the strength of Colonel and Pati, but on the other hand there is a shortage of Lt. Col. and below. From this condition, a common thread can be drawn between the extension of the retirement age and the excess personnel of Colonel and Pati.

The second is the policy of providing leadership cadres through secondary level general development education which is not in line with the career development policy at the rank of Colonel in each Force. For example, within the Indonesian Army, the Headquarters designated the positions of Colonel and Pati as Jab-Pil, meaning that only "elected" officers should have held these positions. Theoretically, the selection process is carried out through a class IV position determination session. However, in practice, the selection process was carried out early at the time of selection to enter Seskoad, because all Seskoad graduates are almost certain to occupy class IV positions.

The third is a career development system for TNI personnel that "half forces" each personnel to have a career as TNI soldiers until the maximum retirement age. Formally, this approach can be seen from the career development policies set out in Government Regulation Number 39 of 2010 concerning the Administration of TNI Soldiers. Article 21 (3) states that, "Career Soldiers who finish running the First Service Association period and do not apply for resignation for some reason are considered to be continuing the Advanced Service Association". This rule makes it very difficult for the personnel power coach to maintain the balance of the personnel composition through controlling the personnel input and output, because there is no opportunity for the personnel force coach to separate personnel for the benefit of the organization.

Organization Kodam V/Brawijaya is part of the territorial military command area which is unique compared to other Kodam, where the uniqueness of Kodam V/Brawijaya is its territorial area which only covers East Java province and is not a special area such as Kodam Iskandar Muda in Aceh, or Kodam Jaya in DKI Jakarta province. Kodam V/Brawijaya was chosen as the location for the research with the consideration that since the formation of Kodam V/Brawijaya it has been a regional military command that completely has one territory, namely the province of East Java which is different from other Kodam such as Kodam I which oversees four provinces in Sumatra, Kodam II/Sriwijaya oversees five provinces, Kodam III/Siliwangi in charge of the two provinces of West Java and Banten, and several other military Regional Commands which are not purely in charge of one province so that it is considered to facilitate the conduct of research.

With regard to career development for officers, as we all know, career development for officers at the TNI institution is different from career development carried out by other agencies and organizations. It can be seen that although the TNI AD consists of several special branch corps, in the career development of its officers it does not consider its branch corps for officers who occupy positions in Multikorps units, career development is carried out purely based on the policy of transferring positions as stated in the Kasad Decree. 483 concerning career development for TNI AD officers, which includes:Dismissal and Appointment in Position, Transfer of Position, Promotion and Selection of Education. Sometimes there are questions about not considering the existing corps in the career development of TNI AD officers, in general, questions usually arise just because an officer is a leader who is not according to his field, this shows that career development for officers in the TNI AD organization does not only pay attention to competence but more on many things such as leadership, talent scouting, psychology, track record assessment lists to the sociometric elements.

\section{LITERATURE REVIEW}

\subsection{Policy Implementation}

Van Meter and Van Horn (1975) as quoted by Agustino (2008: 139), provide a definition of policy implementation as actions taken either by individuals or officials or government or private groups that are directed towards the achievement of goals. objectives outlined in the policy decision [1]. According to Nugroho (2008: 432), policy implementation is, in principle, a way for a policy to achieve its goals, nothing more or les [2]. To implement public policy, there are two choices of steps, namely directly implementing it in the form of a program or through the formulation of a derivative or derivative policy from the public policy.

\subsection{Career Development Theory}

According to Gibson et al (2000) career is a sequence of experiences and activities related to work and which creates certain attitudes and behaviors in a person [3]. According to Handoko (2000) career is all jobs or positions that are handled or held during a person's working life [4]. A career consists of a sequence of experiences or a series of work held during a person's life that 
provides continuity and tranquility to create certain attitudes and behaviors. According to Robert (2001) organizational-centered career planning focuses on jobs and on building a career path that provides a place for the logical progress of people, among various jobs in the organization [5]. These paths are those that individuals can follow to balance specific organizational units. For example, a person might enter the sales department as a sales advisor, then be promoted to financial reporting, sales manager, and eventually vice president of sales.

Career development includes career management and career planning. Understanding career development in an organization requires an examination of two processes: first, how each person plans and implements development programs; and second, how the organization designs and implements its career development programs. The career planning process is the process by which individual workers identify and take steps to achieve their career goals. Career planning involves identifying career-related goals and developing plans to achieve those goals. Career management is the process by which organizations select, assess, assigns and develops employees to provide a weighted pool of people to meet future needs (Simamora, 1987: 505) [6].

\subsection{Leadership Theory}

Leadership according to Handoko (2003: 468) is: "Leadership involves an unequal distribution of power between leaders and group members, leaders have the authority to direct various activities of group members" [7]. Pamuji (1993: 7) states that leadership is a personality that has influence, which results in a conclusion that leadership is the result of a one-sided influence [8]. They recognize that leaders can have traits that differentiate them from followers, but they generally fail to acknowledge any reciprocity or interaction of leadership situations. In the context of behavior, leadership is the art of creating ideological conformity or agreement, the art of creating ideological conformity is relevant to power and influence. It is said that to help leaders advance he proposes the idea of a "power triangle" whose components are communication, recognition and influence.

\section{RESEARCH METHOD}

\subsection{Research Design}

This research uses a grounded theory strategy and is inductive in nature, which means that the theory is built from data or is grounded in the data, where the researcher immediately jumps into the field with the scope of the various branches in Kodam V/Brawijaya, without bringing a conceptual design, theories, and certain hypotheses.

\subsection{Research Focus}

In this research, the observed aspects include:

1) Implementation Career Development for TNI-AD Officers in Kodam V/Brawijaya with the indicators:

a. Dismissal and Appointment in Position andTransfer of Position

b. Promotion

c. Educational Selection

2) Supporting and inhibiting factors Implementation of TNI-AD Officer Career Development at Kodam V/Brawijaya with the indicators:

a.Internal Soldier in the form of welfare, morale, mental, discipline and skills of soldiers.

b.External in the form of mechanism and budget policies in developing TNIAD careers.

\subsection{Data Analysis Techniques}

According to Moleong (2012), the data analysis process begins by examining all available data from various sources, namely from interviews, observations that have been written in field notes, personal documents, official documents, pictures, photos, and so on. [9]. There are a lot of data, after reading, studying, and analyzing, the next step is to reduce the data by means of abstraction. Abstraction is an attempt to make a core summary, process and statements that need to be maintained so that they remain in it. The next step is to arrange it in units. The units are then categorized in the next step. The categories are created while coding. The final stage of this data analysis is to check the state of the data. After completing this stage, begin this stage, now the data interpretation stage in processing the provisional results into a substantive theory using several specific methods will begin. 


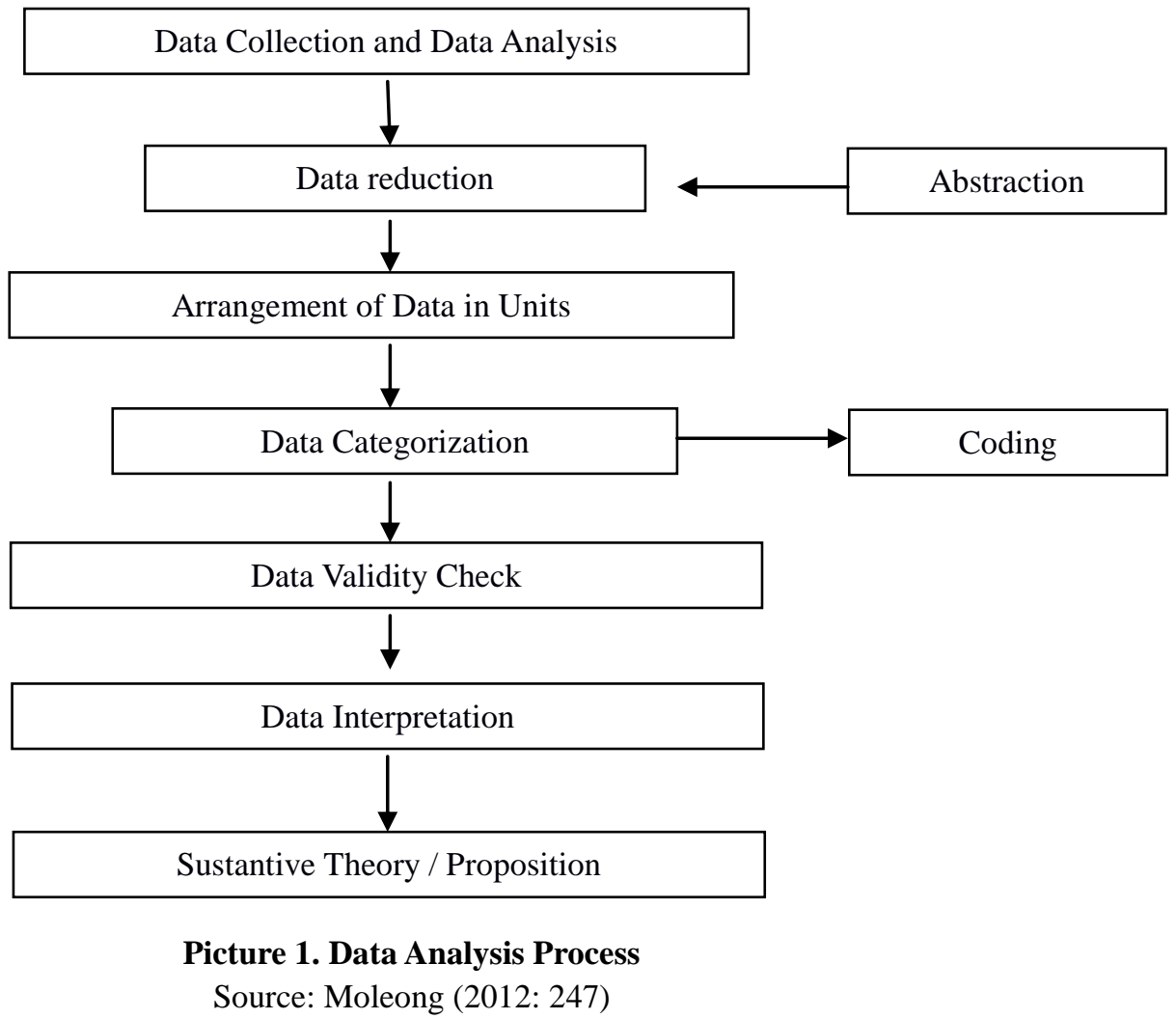

\section{DISCUSSION}

\subsection{Implementation Career Development for TNI-AD Officers in Kodam V/Brawijaya}

Phenomenon Career Development for TNI-AD Officers in Kodam V/Brawijaya can not be separated from In relation to the relevance of management, the organization has carried out a management function, namely actuating, in this case according to research data on the military organization of Kodam V/Brawijaya carrying out activities in carrying out career development within the organization and carrying out the control function (controlling) of the results that have been achieved. In this context in accordance with the opinion of George R. Terry (1964: 3) in Pamudji (1993: 7) regarding management functions consisting of: planning, organizing, actuating and controlling, it is the actuating function which contains the implementation of Career Development for organizational members who then penetrate into other functions [8].

Basically Career Development for TNI-AD Officers in Kodam V/BrawijayaThis is inseparable from the management system in career development which includes career management and career planning. Understanding Career Development in an organization requires an examination of two processes: first, how each person plans and implements development programs; and second, how the organization designs and implements its Career Development programs. The career planning process is the process by which individual workers identify and take steps to achieve their career goals. Career planning involves identifying career-related goals and developing plans to achieve those goals. Career management is the process by which organizations select, assess, assigns and develops employees to provide a weighted pool of people to meet future needs. (Simamora, 1987: 505) [6]. PhenomenonCareer Development for TNI-AD Officers in Kodam V/Brawijaya This is one of several interesting things and at the same time is the staring point of a phenomenon to be studied. Theoretically, this can be studied with a variety of existing career development and management theories.

An understanding of the career development of TNI AD officersIn essence, it is a systematic, planned effort that includes structures and processes that produce officers who are suitable and in line with the needs of the organization. ImplementationThe career development of TNI-AD officers at Military Regional Command V/Brawijaya is relevant to the theory Van Horn (1975) as quoted by Agustino (2008: 139) [1], provides a definition of policy implementation as actions taken either by individuals or government officials or groups that are directed at achieving the goals outlined in policy decisions, in this case outlined in the KEP. KASAD No. 483 of 2014 concerning the Career Development of TNI AD Officers has been implemented at every stage of career development for TNI officers with the aim that the implementation of tasks assigned to personnel can be carried out with support for the implementation of policies made. 


\subsubsection{Dismissal and Appointment in Position and Transfer of Position}

Termination and Appointment in Position and Transfer of Position is a form of career coaching in the form of PThe assignment of an officer in a position is a form of leadership trust in an officer which results in responsibility for the person concerned. Therefore, placement in a position must be able to develop the potential of the person concerned in a higher position and be adjusted to his abilities.

Dismissal and appointment of positions and transfer of positions as part of the career development of officers is essentially an effort, job and activity to obtain military officers with the quality and quantity needed to meet the needs of the TNI AD organization in carrying out the main duties of the TNI AD. In order to achieve effective, efficient and right on target both qualitatively and quantitatively, the termination and appointment of positions and transfers of positions must be guided by the KEP. KASAD No. 483 of 2014 concerning the Career Development of existing Army Officers. In this case, each level is required to provide qualified personnel who are ready to carry out their duties as soldiers of the Indonesian Army.

Dismissal and Appointment of Position and Transfer of Position as part of career development for officers requires an arrangement of officer resource system that leads to a system of Dismissal and Appointment in Position and Transfer of Position as part of an open, transparent, accountable and competency-based career development for officers. Dismissal and Appointment in Position and Transfer of Positions as part of the career development of officers, of course, requires an accurate calculation between the number of personnel needed according to the composition of ranks, branch groups and sources of soldiers with the number of personnel who will retire in the face of the availability of a good number of positions in existing units. existing or units that will be formed according to the plan in the TNI AD Strategic Plan, this is in line with the application of the principle of zero growth and the MEF policy. Determination of job requirements in the context of Officer Career Development, must be based on a quantitative approach with qualitative analysis of existing officers and the number of needs to be used, however the quality of prospective officers who will occupy positions remains a priority. A realistic and applicable approach, namely the need for a position to be calculated based on the real conditions in the field and the correct prediction of separation/retirement in order to avoid the accumulation of personnel in the medium and long term. however, the quality of prospective officers who will take up positions remains a priority. A realistic and applicable approach, namely the need for a position to be calculated based on the real conditions in the field and the correct prediction of separation/retirement in order to avoid the accumulation of personnel in the medium and long term. however, the quality of prospective officers who will take up positions remains a priority. A realistic and applicable approach, namely the need for a position to be calculated based on the real conditions in the field and the correct prediction of separation/retirement in order to avoid the accumulation of personnel in the medium and long term.

Career development for TNI AD Officers within Kodam V/Brawijaya in the form ofdismissals and appointments and transfers indicate that career development in an organization requires an examination of two processes: first, how each person plans and implements development programs; and second, how the organization designs and implements its career development programs. The career planning process is the process by which individual workers identify and take steps to achieve their career goals. Career planning involves identifying career-related goals and developing plans to achieve those goals. Career management is the process by which organizations select, assess, assigns and develops employees to provide a weighted pool of people to meet future needs. (Simamora, 1987: 505)[6].

This is in line with views of theorists and practitioners who study military sociology Sociology according to Bredow (2000: 665) [10], there are five main fields of study of military sociology. First; internal organizational problems, analyzing small group processes and military rituals with the aim of identifying disciplinary and motivational problems and describing the ways in which the military subculture was formed. Second; internal organizational problems in combat; where in this case the analysis includes the selection of military officers, ranks, and evaluation of battle motivation. Third; the armed forces and society, which examines the image of the profession related to the impact of social and technological changes, the profile of the recruitment of the armed forces, the training and education problems of soldiers, and the role of women in the armed forces. Fourth; military and political:

\subsubsection{Promotion}

At the TNI AD Institution, promotion/promotion is one of the career development systems and organizational needs, rank can support the upholding of the authority and responsibility given to the person concerned. Pada, in essence, rank is the validity of authority and responsibility in the hierarchy of officers based on the qualifications possessed by an officer as part of career development. Rank is directly related to granting a position, so that rank supports the upholding of the authority and responsibility given to the person concerned. 
The results of the observation show that career development is in the form of promotion of officers in Kodam V/Brawijaya has been in accordance with the procedure starting with the proposal of the proposed officer for promotion, in which the proposal has listed the corps data and current rank, the concept and sprint of his appointment, the source of the officer, the education he has attended, the list of assessments and the value of his suit and will occupy what rank. After the preparation of the proposals has been completed, a promotion session is held according to the structure then the results are compiled for updating

In a theoretical perspective, the promotion of an officer as a form of career development has reflected that the TNI AD institution has carried out coaching related to human resource issues that has always been in the spotlight and hopes for TNI AD personnel to always continue to compete in order to survive in work in the organization. Human resources have a major role in every activity of an organization. Even though there are many facilities and infrastructure and all existing resources, without the support of professional and competitive human resources, the goals he does will not run well, directed, systematically in achieving the ultimate goal of the work he does. This means that human resources are the main key that must be considered in an organization by paying attention to all its needs. Human resources will determine the successful implementation of organizational activities, both civilian and military. For this reason, in achieving organizational goals, adequate, reliable, creative competence of human resources is needed in encouraging the performance of its members.

Promotion in the form of career coaching is relevant to the characteristics of career effectiveness (Simamora, 1987: 509): Change and development are part of the profession. Changes in the profession itself require new knowledge and skills to be applied; for example, medicine and engineering will always need new information and technology[6]. Other professions have also changed markedly. Individuals who arenotbeing able to adapt to these changes takes on financial risks and job loss. Organizations certainly gain the benefits of the suitability of the individuals in them. Therefore, career adaptability implies the most advanced application of knowledge, skills and technology in a career.

\subsubsection{Educational Selection}

The Indonesian National Army as the main component of the national defense system is required to always have the ability to keep up with the development of science and technology in order to anticipate future challenges, so the implementation of TNI $\mathrm{AD}$ education must always be adjusted and developed so that it is always in accordance with the demands of the main duties of the TNI-AD by always anticipating development of education that applies within the TNI AD. Educational Selection is one of the pillars in forming professional and reliable officers who have an identity as a soldier. Educational selection efforts must be initiated from the stage of providing personnel and selecting candidates for TNI soldiers who have quality in the Tri aspect of the basic education pattern. If we are faced with the readiness of soldiers to develop defense technology and modernization of Alutsista according to the demands of the MEF, efforts to increase capacity are carried out through education, enhancing science, technology, skills and behavior of soldiers. Furthermore, career development in the form of educational selection is useful for increasing the ability of officers through education, of course, very much depends on two aspects, namely, the personal aspects of the soldiers (personnel) themselves and aspects of educational institutions (educational institutions). Efforts made in the career development of officer soldiers through educational selection, from the personnel aspect, namely organizing a fair, objective, open and rigorous selection to recruit qualified prospective students.

It is hoped that the career development of officers in the form of educational selection can create well-educated and welltrained professional TNI soldiers, and the improvement of the education system at all levels of education within the TNI must be continuously improved. The steps for education development that can be carried out are by striving for an increase in educational support every year so that gradually the improvement in aspects of the education component will increase. There is an increase in the education budget, prioritized for improving education operations, by continuing to reform the ten components of education at the central level of education institutions, then to educational institutions at the regional level, and selectively and realistically reforming educational institutions at the branch or function level.

Education Selection for officers is a training development of competency-based soldier education and training. Educational programs for soldiers to prioritize an interactive and conducive teaching and learning process, through mastery of science and technology as a prerequisite for intellectual development of personnel, in order to have sharp perceptions, careful analysis, especially education at officer level and broad insight, so as to produce reliable graduates. and professional both in terms of quality and quantity.

Educational Selection as a future career development must prioritize quality and not just be implemented. Therefore, the role of instructors and lecturers is very important. The performance of Indonesian Army educators is very important to be considered and evaluated because educators carry out professional tasks, meaning that tasks that can only be done with special competencies that are obtained through education and training programs. The performance of the TNI AD educators is directed at increasing the 
competence in implementing the education/training process inside and outside the classroom. Efforts to increase professionalism must of course be in line with efforts to provide appreciation, increase welfare, and protect educators.

The results of observations in the field show that the career development of officers in the form of educational selection is divided into first education, formation education, general development education, specialization development education, science and technology development education and transitional education. This selection of education for officers is basically aimed at increasing the ability of officers to anticipate changes in the national environment that occur so rapidly that they are difficult to predict. The actions of an officer are more or less influenced by their educational background and their branches. Therefore, the education that has been and will be taken by an TNI AD Officer who is in accordance with their respective background and branch will determine their career and dedication in carrying out their duties as TNI AD Personnel.

On the resource side here will focus on the resources of students and educators or gumil or teaching staff in military education institutions. Educators in military educational institutions must be professional educators with the main task of educating, teaching, guiding, directing, training, assessing, and evaluating students on the educational path. This main task will be effective if the teaching staff has a certain degree of professionalism which is reflected in the competence, proficiency, proficiency, or skills that meet certain quality standards or ethical norms. This is in line with the opinion of Sudarmanto (2009) which states that educators are human resources in the TNI AD organization who are very decisive for success or failure in achieving organizational goals [11]. According to Schultz, human resources are human capital that functions from expertise (skills), experience, and knowledge). Meanwhile, according to Davenport, human capital is the capacity of human resources which consists of abilities (including knowledge, skills, talents), behavior, effort and time.

The education selection carried out was also in accordance with the opinion of Wexley and Yukl (1976: 282) arguing: training and development are terms reffering to planned efforts designed to facilitate the acquisiton of relevant skills, knowledge, and attitudes by organizational members [12]. Can be interpreted :Training and Development are the right conditions for planning design efforts to facilitate the acquisition of relevant skills, knowledge, and attitudes by organizational members.

\subsection{Factors that support and hinder Implementation Career Development for TNI-AD Officers in Kodam V/Brawijaya}

\subsubsection{Internal Soldier in the form of welfare, morale, mental, discipline and skills of soldiers.}

Career development for officers at Kodam V/Brawijaya consisting of dismissal and appointment of positions and transfer of positions, promotion and selection of education is influenced by internal soldiers in the form of welfare, morale, mental, discipline and skills of soldiers. It is hoped that the fulfillment of the welfare of the officers of these soldiers can make TNI personnel become soldiers who have an identity, are professional, trained, educated, do not have practical politics, and are not.do business. This is in accordance with the mandate issued by Law Number 34 of 2004 concerning the TNI. In addition to rejuvenating defense equipment, Indonesia should also build defense forces through its human resources. Because humans are the main essence of the operation of defense equipment and real armed forces.

The morale of TNI soldiers as the main guard in the field of defense and security forces and socio-political forces in reality is also inseparable from various obstacles, some of which are sticking out in the headlines of several media that reveal the indiscipline of individual soldiers who have violated the law. In addition, the unsuitable placement of officers can have various negative effects, such as decreased morale of soldiers, tasks that are not well controlled, tendencies of indifference, careless performance of soldiers, and so on.

Mentalor the term mentality is a way of thinking or the concept of human thought to be able to learn and respond to something. Mental is another word for mind. So, mentality can be said as a way of thinking about something. The mentality of a soldier is an influential factor in the implementation of personnel coaching because the soldier's mentality is a reflection of the soldier's soul getting stronger, the faith is getting stronger, so that it leads to a clear mind and allows the emergence of various good ideas and strength to be able to prevent various kinds of violations that can harm. for individuals, families and TNI AD institutions themselves.

Talking about the discipline of soldiers, discipline requires adherence to organizational rules by all members. The goal is not only on the physical law but also on the behavior of the person who receives discipline and is not based on coercion from others and is not driven by self-interest but is based on the belief in the need for a complete and solid unity. So discipline is the key to the success of an organization in achieving the goals of the Unity organization. 
The skills of a soldier will affect the success of the implementation of an officer's career coaching itself. Proficiency in this case is the potential to get the right person in the right position done by TNIAD is based on the abilities, skills and talents and achievements of soldiers in the field. In this case, Spersad strives to organize personnel development consistently, integrated, directed, planned and well integrated in order to realize the professionalism of soldiers.

The theoretical perspective on the side of internal factors or the obstacles from the side of the soldier himself in the career development of officer personnel is inseparable from character building for the personnel, this is in accordance with JS's opinion. Prabowo in his book entitled "Military Leadership, Character and Integrity" said that a soldier is not only clever and clever enough. An officer soldier must have self-integrity, that is, only words and deeds and has character. Prabowo further explained that what is meant by character is the ability to uphold moral principles. Officer soldiers who are only clever or smart will not be able to complete their main tasks, but soldiers who have character and self-integrity will make the soldiers able to complete the tasks they are assigned. This paper not only underlines the intelligence embodied in competence, it also needs character and integrity. Without sufficient intelligence he will not be able to analyze the challenges of the future so that he will certainly not be able to form a vision of the future.

The internal factor of the soldier influencing the career development of the officer itself is also in line with the opinion of John Maxwell in his book entitled "Developing the Leaders Around You", saying that the success of a person depends on his ability to be able to build his own potential. From the point of view of a leader in the organization will develop and become strong when a leader succeeds in building peoplepersonthey lead has the quality as a leader. Maxwell's theory does not include the issue of personality integrity which is very influential on the emergence of quality as expected. This personality integrity is important so that the quality displayed is a quality that emanates from the real person. In a personal state experiencing split personality, the quality that is displayed is just a mere pretense. This paper includes the integrity variable as the source of all the qualities expected to emerge from members of the TNI in a future full of very complex challenges.

The morale of soldiers greatly affects the level of violations committed by soldiers in the unit. According to Copeland (1980), moral qualities include discipline, self-control, self-respect, loyalty, confidence in oneself and a deep understanding of self-pride and corps [13]. Various studies have been conducted and show a correlation between the level of morale of soldiers and the level of disciplinary offenses. The soldiers' low morale could be seen from several indications. First, there are many cases or problems of psychiatric disorders and disorders that are scientifically called neuro-psychiatry. Second, there are many disciplinary violations, insubordination, criminal acts, desertions and other negative things related to violations of the law.

\subsubsection{External in the form of mechanism and budget policies in the career development of the Indonesian Army.}

As we all know, career development for officer personnel is basically aimed at making the output of officers produced high capability and performance as part of the determination to build a strong TNI is not an easy thing to achieve if it is not based on hard work supported by good, synergic and sustainable policies. The realization of officer career coaching is more directed at fostering micro aspects and fostering human resources (Binteman) leading to fostering macro aspects. The micro aspect includes activities in controlling individual aspects which in the success of its activities will determine the readiness of officers to manning the TNI organization. While the macro aspect includes activities in controlling the demands of organizational manning needs and requirements which include strength planning,

The embodiment of the strategic plan of the TNI's strength which is embodied in the development of the TNI's strength towards the minimum basic force (MEF) and conformity with Presidential Regulation number 10 of 2010 concerning TNI Organizational Structure requires the support of professional and high-performance officer personnel so that organizational readiness can be realized as expected. External influences that can affect the restructuring of the career development of highperformance TNI officers, namely the optimization of the implementation of RI Law Number 34 of 2004 concerning the TNI, the national bureaucratic reform policy and the policy of maintaining the number of TNI personnel in accordance with the existing numbers by implementing the Zero Growth policy. . This external influence must be addressed and carefully scrutinized so that policy synchronization can become an accelerator in improving the performance of TNI officers. This is in line with the opinion that environmental, organizational and occupational characteristics all influence various aspects of career management, including the degree to which the organization assists and funds individual career planning, the scope of job opportunities inside and outside an organization, the types of career paths available, and interactions. How to work and family obligations (Simamora, 1987: 507) [6]. 


\section{CONCLUSIONS AND SUGGESTIONS}

\subsection{Conclusion}

1) Implementation training for soldier personnel carried out at Kodam V/Brawijaya according to the research results can be concluded as follows:

a) Officer Career Development in the form of dismissal and appointment of positions and transfer of positions of officers is carried out by taking into account the periodization, position and parameters of officers' positions in accordance with the norms and process of lawyers.

b) Implementation of promotion for officers as a form of career coaching consists of promotion of awards and regular promotions, the implementation of which begins with a proposal, conducts a promotion session according to its structure, then the results are compiled to be updated.

c) Implementation of selection education for officers as part of career development is divided into various categoriesstages with the aim of increasing the ability of officers to anticipate changes in the national environment

2) The factors that influence the career development of TNI AD officers consist of Internal Factors in training soldiers in the form of welfare, morale, mental, discipline and skills of soldiers and Internal Factors in coaching soldiers in the form of welfare, morale, mental, discipline and skills of soldiers in personnel training at Kodam V/Brawijaya

a) Career development for officers must be supported by welfare in order to support high morale and mentality as well as discipline and skills for officers in carrying out their duties and challenges ahead.

b) The Policy Mechanism for the career development of this officer begins with dismissal and appointment in a position and transfer of position, rank and selection of education will not run optimally if it is not supported by adequate funding sources

3) The major proposition in this research is implementation Career Development for TNI AD Officers is focused on the policies of dismissal, appointment in position, transfer of positions, ranks and educational selection aimed at the successful implementation of TNI AD duties.

\subsection{Implications of Research Results}

1) Theoretical Implications

a. Research conducted on the implementation of officer career coaching This has supported the theory of George Edward III which emphasizes that there are four main issues for effective policy implementation, namely communication, resources, disposition and bureaucratic structure.

b. The communication aspect in research with regard to how policies are communicated to the organization and/or the public get attitudes and responses from the parties involved

c. Resources or resources in research with regard to the availability of supporting resources, the availability of human resources. This is related to the successful implementation of public policies to bring these policies to work effectively.

d. Disposition with regard to research related to the willingness of the implementers to carry and implement the policy, but this must be supported by the suitability of the bureaucratic organization that organizes the implementation of public policy.

2) Practical Implications

The implementation of career coaching in an implementative manner is influenced by the development cycle. Internal factors in the TNI AD soldiers who generally influence this career development are lack of fulfillment of welfare, which will affect morale, mentality, discipline and skills of soldiers in career development at Kodam V/Brawijaya which in general is also due to the low existing defense budget.

\subsection{Recommendation}

Based on the findings in this study, several suggestions will be presented, both theoretical and practical. This research is a case study and is limited to only researching Career Development for Officers at Kodam V/Brawijaya in order to create professional Army soldiers and this is a research limitation that needs to be followed up. In this context, the following suggestions are needed:

1) Theoretical Suggestions

Further research should be carried out by developing a perspective from career development within the TNI AD and it is recommended that researchers carry out direct observation at every mission implementation activity at the research location, to be able to clearly see the career development process in various forms of cases and varied settings. 
2) Practical Suggestions

It should be done changes that are not totally interpreted, but are gradually related to the problem of the accumulation of officers and the lack of existing positions. Apart from that, in the career development of these officers, the issue of transparency must be put forward to foster the trust of officers for the advancement of the TNI in the future.

\section{REFERENCES}

1. Agustino, Leo. 2008. Dasar-dasar Kebijakan Publik. Bandung: Alfabeta

2. Nugroho, Rianto, D. 2008. Kebijakan Publik: Formulasi, Implementasi dan Evaluasi. Jakarta:PT. Elex Media Komputindo.

3. Gibson, James L., John M. Ivancevich, dan James H. Donnelly. 2000. Organizations Behaviour, Structure and Process. 8th ed. Boston: Richard D. Irwin Inc.

4. Handoko, T. Hani. 2000. Manajemen Personalia dan Sumber Daya Manusia,. Edisi ke 2. Yogyakarta: BPFE.

5. Robert A. Dahl. 2001. Perihal Demokrasi, terj. A. Rahman Zainuddin (Jakarta: Yayasan Obor Indonesia, 2001)

6. Simamora, Henry, 2001,. Manajemen Sumber Daya Manusia. Cetakan Ketiga. Yogyakarta. YPPKN.

7. Handoko, T.Hani, 2003. Manajemen Personalia dan Sumber Daya Manusia,. Yogyakarta, BPFE-Yogyakarta.

8. Pamudji, S 1994. Profesionalisme Aparatur Negara Dalam Meningkatkan Pelayanan Publik. Jakarta: Widyapraja No. 19 Tahun III, IIP.

9. Moleong, Lexi J., 2012, Metode Penelitian Kualitatif, Remaja Rosdakarya, Bandung.

10. Bredow. 2000. Memahami Kembali Sosiologi. Yogyakarta: Gadjah Mada University Press.

11. Sudarmanto. 2009. Kinerja dan Pengembangan Kompetensi SDM. Yogyakarta: Pustaka Pelajar.

12. Wexley dan Yukl. 1976. Menjadi Guru Profesional. Bandung: Remaja Rosdakarya.

13. Copeland, L. O. 1980. Principles of Seed Sciencce and Technology. Minneapoli, Minnesota. Manila. 